\title{
The Temperature and Time Influence of Immersion in Water Solvent against Formaldehyde Salted Level Belanak Fish (Mugil cephalus)
}

\author{
Mohammad Farid, Akyunul Jannah, Anik Maunatin \\ Jurusan Kimia Fakultas Sains dan Teknologi Universitas Islam Negeri Maulana Malik Ibrahim Malang \\ Email: akyunul_jannah2008@yahoo.com
}

\begin{abstract}
The salted fish is one that is frequently consumed foods by the general public, but people do not realize that a lot of salted fish in the market that contained formaldehyde that can endanger the health of the body and is a food that is not suitable for consumption. The purpose of this study was to determine the temperature and the time required for formaldehyde in salted fish can be reduced. The formaldehyde method used to reduce level in foods, especially salted fish is by using immersion in water. Soaking dried fish is done by using variations in temperature and immersion time. Stage of the study was initiated with the addition of making salted fish with formalin at a concentration of $4 \%$. The fish used is fresh mullet. Variations in temperature used is $40^{\circ} \mathrm{C}, 50^{\circ} \mathrm{C}$, $60^{\circ} \mathrm{C}$, and $70^{\circ} \mathrm{C}$ while the variation of time used is $10,15,20$ and 25 minutes. The level of formaldehyde was analyzed by acid kromatofat and UV-Vis. The analysis results of formaldehyde levels using UV-Vis is the best temperature to reduce levels of formaldehyde in salted fish is $70^{\circ} \mathrm{C}$ by $80.2 \%$ and the best time to reduce levels of formaldehyde that is 25 min for $95.6 \%$. Test statistics using Minitab ANOVA variance variant which shows that the influence of the decreased levels of formaldehyde salted fish and produce temperature and the best time is at a temperature of $70{ }^{\circ} \mathrm{C}$ and 25 minutes at a time.
\end{abstract}

Keywords: Mugil chepalus, formaldehyde, salted fish, water solvent

\begin{abstract}
Abstrak
Ikan asin merupakan salah satu bahan makanan yang sering dikonsumsi oleh masyarakat pada umumnya, namun masyarakat tidak menyadari bahwa banyak beredar dipasar ikan asin yang berformalin yang dapat membahayakan terhadap kesehatan tubuh dan merupakan bahan makanan yang tidak layak untuk dikonsumsi.Tujuan dari penelitian ini adalah untuk mengetahui suhu dan waktu yang diperlukan agar formalin dalam ikan asin dapat berkurang. Metode yang digunakan untuk menurunkan kadar formalin pada bahan makanan khususnya ikan asin yaitu dengan menggunakan perendaman dalam air. Perendaman ikan asin dilakukan dengan menggunakan variasi suhu dan waktu perendaman. Ikan asin dibuat dengan penambahan formalin $4 \%$. Ikan yang digunakan merupakan ikan belanak segar. Variasi suhu yang digunakan adalah 40, 50, 60 dan $70{ }^{\circ} \mathrm{C}$ sedangkan variasi waktu yang digunakan adalah 10, 15, 20 dan 25 menit. Analisis kadar formalin menggunakan asam kromatofat dan UV-Vis. Hasil analisis kadar formalin menggunakan UV-Vis adalah suhu yang terbaik untuk menurunkan kadar formalin pada ikan asin yaitu $70{ }^{\circ} \mathrm{C}$ sebesar $80,2 \%$ dan waktu yang terbaik dalam menurunkan kadar formalin yaitu 25 menit sebesar 95,6\%. Uji statistik menggunakan ragam varian minitab ANOVAyang menunjukkan bahwa adanya pengaruh terhadap penurunan kadar formalin ikan asin dan menghasilkan suhu dan waktu terbaik yaitu pada suhu $70{ }^{\circ} \mathrm{C}$ dan pada waktu 25 menit.
\end{abstract}

Kata kunci: Mugil chepalus, formalin, ikan asin, pelarut air

\section{Pendahuluan}

Ikan asin adalah ikan segar yang sudah mengalami proses pengasinan. Salah satu jenis ikan yang dapat digunakan untuk pembuatan ikan asin adalah belanak (Mugil cephalus). Pengasinan ikan merupakan cara untuk menjaga ikan agar tidak cepat membusuk sehingga ikan akan menjadi lebih tahan lama dan awet (Hastuti, 2009). Banyaknya ikan asin yang beredar di pasar tradisional atau modern tidak diimbangi oleh pengetahuan masyarakat mengenai ikan asin yang aman dan baik untuk dikonsumsi. Hal tersebut dibuktikan dengan masih banyak ikan asin yang mengandung formalin yang masih beredar (Kompas, 2013).

Kadar formalin pada ikan asin dapat dikurangi yaitu dengan menggunakan perendaman dalam air, hal ini disebabkan 
karena formalin mempunyai sifat larut dalam air sehingga dengan perendaman dalam air formalin yang ada pada ikan asin akan larut pada pelarutnya yaitu air. Perendaman dalam air dapat dilakukan pada rentang suhu $40-70{ }^{\circ} \mathrm{C}$, sedangkan waktu perendaman dapat digunakan selama 15-25 menit.

Pengujian kadar formalin secara kuantitatif pada ikan asin belanak dapat dilakukan dengan menggunakan yaitu metode asam kromatofat. Asam kromatofat digunakan untuk mengikat formalin agar terlepas dari bahan yang mengandung formalin, formalin bereaksi dengan asam kromatofat yang menghasilkan senyawa kompleks yang berwarna ungu.

\section{Metode Penelitian}

\subsection{Alat dan Bahan}

Alat-alat yang digunakan pada penelitian ini adalah erlenmeyer, gelas kimia, pengaduk, pipet ukur, tabung reaksi, termometer, alumunium foil, oven, cawan porselen, dan spektrofotometer UV-Vis. Sedangkan bahan-bahan yang digunakan adalah ikan asin, air, asam kromatofat, formalin, garam dapur, asam sulfat, dan Bovine Serum Albumin (BSA). biuret

\subsection{Pembuatan Ikan Asin dengan Penambahan Formalin}

Ikan asin belanak sebanyak $\pm 50 \mathrm{~g}$ dicuci kemudian direndam dalam $100 \mathrm{~mL}$ larutan garam. Garam yang digunakan mengikuti berat ikan asin yaitu dengan menggunakan perbandingan 2:1 (berat ikan : berat garam), Formalin 4\% ditambahkan pada ikan saat perendaman. Ikan direndam selama 24 jam, kemudian dijemur sampai kering pada terik matahari selama 20 jam (2 hari).

\subsection{Analisis Kadar Air Ikan Asin}

Cawan dipanaskan dalam oven pada suhu $100-105{ }^{\circ} \mathrm{C}$ sekitar 15 menit dan disimpan dalam desikator sekitar 10 menit. Langkah tersebut dilakukan hingga diperoleh berat cawan yang konstan. Sampel ikan asin sebanyak $5 \mathrm{~g}$ dimasukkan ke dalam cawan dan dikeringkan pada suhu 30-37 ${ }^{\circ} \mathrm{C}$ selama sekitar 30 menit. Setelah itu, didinginkan dalam desikator dan ditimbang kembali. Perlakukan tersebut diulangi hingga diperoleh berat cawan dan sampel yang konstan. Kadar air dalam ikan asin dihitung menggunakan rumus berikut.

Kadar air $=\frac{(b-c)}{(b-a)} \times 100 \%$

\subsection{Analisis Kadar Protein Ikan Asin \\ 2.4.1 Pembuatan Kurva Standar BSA}

Larutan BSA $5 \mathrm{mg} / \mathrm{mL}$ digunakan sebagai standar. Enam buah tabung reaksi diisi dengan larutan BSA masing-masing 0 (blanko); 0,1;0,2;0,4;0,6;0,8 dan 1,0 mL, kemudian ditambah hingga volumenya 4 $\mathrm{mL}$ akuades dan $6 \mathrm{~mL}$ pereaksi biuret. Selanjutnya, sampel diinkubasi pada suhu kamar selama 30 menit sampai terbentuk warna ungu yang sempurna dan diukur serapan sampel.

\subsubsection{Penentuan Kadar Protein Ikan Asin}

Penentuan kadar protein ini dilakukan sebelum dan sesudah perlakuan. Ikan asin sebanyak $1 \mathrm{~g}$ ditambahkan $20 \mathrm{~mL}$ akuades, disaring dan dimasukkan ke dalam labu ukur $100 \mathrm{~mL}$. Selanjutnyam $1 \mathrm{~mL}$ larutan sampel ditambahkan hingga volume $4 \mathrm{~mL}$. Setelah itu, $6 \mathrm{~mL}$ pereaksi biuret ditambahkan dalam sampel dan dihomogenkan. Sampel diinkubasi salama 30 menit dalam suhu ruang hingga membentuk warna ungu. Selanjutnya diukur absorbansinya dengan menggunakan $\mathrm{UV}-\mathrm{V}$ is pada panjang gelombang $540 \mathrm{~nm}$.

\subsubsection{Uji Organoleptik Ikan Asin}

Uji organoleptik pada daging ikan asin meliputi parameter bau, tekstur dan warna. Rentang skala uji mutu hedonik untuk aroma yaitu sangat tidak anyir (0), tidak anyir (1), agak anyir (2), anyir (3), sangat anyir (4). Sedangkan untuk tekstur dengan 5 skala yaitu sangat lembut (0), sedikit lembut (1), lembut (2), kasar (3) sangat sangat kasar (4). Rentang skala 
untuk warna adalah putih agak coklat (0), putih cerah (1), putih agak kuning (2), coklat (3) dan coklat tua (4).

\subsection{Penentuan Suhu Perendaman terhadap Kadar Formalin}

Ikan asin sebanyak $5 \mathrm{~g}$ ditambahkan $200 \mathrm{~mL}$ air. Sampel dipanaskan pada berbagai suhu yaitu 40, 50, 60 dan $70{ }^{\circ} \mathrm{C}$ selama 15 menit. Setelah itu ikan asin diangkat, didinginkan dan dikeringkan. Ikan asin dari proses pengeringan dianalisis kadar formalinnya. Perlakuan ini dilakukan pengulangan sebanyak tiga kali.

\subsection{Penentuan Lama Perendaman terhadap Kadar Formalin}

Lima gram ikan asin ditambahkan 100 $\mathrm{mL}$ air, kemudian dilakukan perendaman ikan asin selama 10, 15, 20, dan 25 menit pada suhu perendaman optimum yang diperoleh dari penelitian sebelumnya. Sampel diangkat, didinginkan dan dikeringkan. Setelah itu, sampel dianalisis kadar formalinnya. Perlakuan ini dilakukan pengulangan sebanyak 3 tiga kali.

\subsection{Analisis Kadar Formalin}

\subsubsection{Pembuatan Kurva Standar}

Kurva standar dibuat dengan memvariasi konsentrasi larutan formalin yaitu, $0 ; 0,05 ; 0,1 ; 0,5 ; 0,75 ; 1,0 ; 1,5 ;$ dan 2 ppm. Larutan formalin $2 \mathrm{~mL}$ ditambahkan $0,2 \mathrm{~mL}$ asam kromatofat $0,4 \%$ dan $3 \mathrm{~mL}$ asam sulfat. Sampel dipanaskan selama 20 menit pada suhu $100{ }^{\circ} \mathrm{C}$. Selanjutnya diukur absorbansi dengan spektrofotometer pada panjang gelombang $562 \mathrm{~nm}$. Pada perlakuan ini diperoleh data persamaan garis $\mathrm{y}=\mathrm{ax}+\mathrm{b}$, dimana $\mathrm{x}$ adalah konsentrasi formalin dan y adalah absorbansi sampel.

\subsubsection{Uji Kadar Formalin}

Sampel ikan asin sebanyak $5 \mathrm{~g}$ ditambahkan $100 \mathrm{~mL}$ air, kemudian diaduk dan disaring (Salosa, 2013). Filtrat sampel sebanyak $2 \mathrm{~mL}$ ditambahkan 0,2 asam kromatofat $0,4 \%$ sebanyakmL $0.2 \mathrm{~mL}$ dan asam sulfat $3 \mathrm{~mL}$ (Rinto dan Susila, 2009).
Sampel dipanaskan selama 20 menit pada suhu $100{ }^{\circ} \mathrm{C}$ dan didinginkan. Absorbansi diukur dengan spektrofotometer pada panjang gelombang $562 \mathrm{~nm}$. Data absorbansi sampel dimasukkan pada persamaan garis linier dari kurva standar.

\section{Hasil dan Pembahasan}

\subsection{Pembuatan Ikan Asin}

Suharna (2006) menyatakan bahwa penggunakan penggaraman basah dalam pembuatan ikan asin mempunyai bertujuan untuk mengetahui konsentrasi garam yang dicampurkan pada ikan. Hasil penggaraman basah ikan relatif baik karena ikan direndam dalam larutan garam sehingga larutan garam tersebut akan menyerap secara merata ke seluruh pori-pori kulit ikan. Selain itu dengan penggaraman basah pada proses penggaraman dapat diberi atau dicampurkan dengan larutan lain seperti formalin.

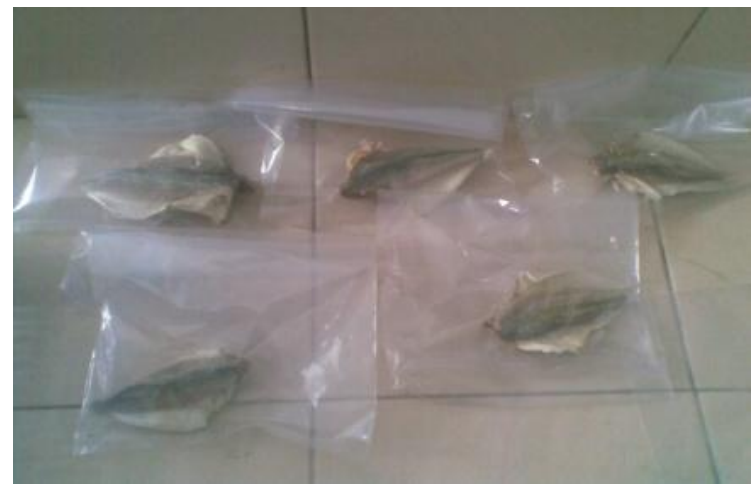

Gambar 1. Ikan asin dengan formalin

\subsection{Analisis Kadar Air Ikan Asin}

Persentase kadar air dari ikan asin yang diberi formalin adalah 0,08\% sedangkan ikan asin tanpa formalin 1,8\%. Menurut Susianawati (2006), standar kadar air ikan asin menurut standar nasional SNI 01-2356-1991 batas maksimum kadar air pada ikan asin kering adalah $40 \%$, ikan asin yang biasanya beredar di pasar-pasar tradisional kadar airnya berkisar antara 15$25 \%$.

Perbedaan nilai kadar air ikan asin tanpa formalin dengan ikan asin yang diberi 
formalin, disebabkan ikan asin yang berformalin mempunyai interaksi yang melibatkan senyawa formaldehid dengan air, yang menyebabkan rendahnya nilai kadar air pada ikan asin yang berformalin. Senyawa formaldehid yang bereaksi dengan air melibatkan interaksi gaya tarik dipoldipol atom $\mathrm{O}$ pada molekul formaldehid dan atom $\mathrm{H}$ pada molekul air, karena kedua senyawa ini merupakan senyawa polar, interaksi gaya tarik dipol-dipol berkaitan dengan gaya Van Der Waals (Ketut, ddk., 2008).

Menurut Earle (1979) dalam Ruus (2009), kadar air ikan asin yang diberi formalin lebih rendah dari ikan asin yang tidak diberi formalin, hal ini karena ketika ikan asin diberi formalin terjadi interaksi dipol-dipol antara air dan formalin pada daging ikan asin. Interaksi dipol-dipol yang terjadi pada daging ikan asin karena terdapat gugus formaldehid yang berikatan dengan air yang mengisi ruang pada daging ikan asin yang menyebabkan kadar air ikan asin menjadi rendah. Sedangkan ikan asin yang tidak diberi formalin memiliki kadar air lebih tinggi hal ini karena daging ikan asin sepenuhnya diisi oleh kandungan air yang tidak berinteraksi dengan senyawa lainnya.

\subsection{Analisis Organoleptik Ikan Asin}

Uji organoleptik warna ikan asin tanpa formalin dan ikan asin dengan formalin menunjukkan bahwa nilai rata-rata kesukaan panelis terhadap ikan asin tanpa formalin adalah (putih kekuningan). Warna ikan asin tanpa formalin berbeda dengan ikan asin dengan formalin yaitu dengan nilai rata-rata kesukaan panelis adalah (putih cerah).

Diketahui bahwa tingkat kesukaan panelis terhadap aroma ikan asin tanpa formalin berkisar pada (anyir), sedangkan tingkat kesukaan panelis terhadap ikan asin yang diberi formalin berkisar pada skala (agak tidak anyir). Hasil analisis uji hedonik tekstur pada ikan asin yang telah dilakukan bahwa ikan asin yang berformalin mempunyai tekstur yang kasar pada permukaannya dan dagingnya kenyal, sedangkan ikan asin yang non formalin mempunyai tekstur yang permukaan yang kasar dan keras.

\subsection{Uji Kadar Protein}

Hasil ini menunjukkan adanya perbedaan kadar protein dari ikan asin, rendahnya kadar protein ikan asin yang diberi formalin mengidentifikasikan bahwa ada pengaruh formalin terhadap nutrisi ikan asin. Menurut Berhimpon (2006), saat formalin dipakai mengawetkan makanan, gugus aldehid spontan bereaksi dengan protein-protein dalam makanan, sehingga menyebabkan nilai gizi makanan itu menjadi rendah karena struktur proteinnya berubah.

\subsection{Perendaman dalam Air dengan Variasi Suhu}

Hasil analisis menunjukkan adanya penurunan kadar formalin pada ikan asin, kadar formalin ikan asin tanpa perendaman yaitu 78,0 ppm namun setelah dilakukan perendaman pada suhu optimum yaitu 70 ${ }^{\circ} \mathrm{C}$. terjadi penurunan kadar formalin pada ikan asin. Berkurangnya kadar formalin pada ikan asin disebabkan adanya proses perendaman dengan menggunakan pelarut air. Formalin dalam ikan asin ikut larut dalam air, selain itu berkurangnya kadar formalin dipengaruhi oleh suhu optimum pada $70{ }^{\circ} \mathrm{C}$. Formalin dapat menguap dengan adanya pemanasan sehingga formalin yang ada pada ikan asin juga ikut menguap.

Proses deformalinisasi atau menghilangkan kadar formalin yang terjadi pada ikan asin dengan menggunakan pelarut air. Hal tersebut disebabkan karena adanya perbedaan tekanan osmosis antara daging ikan asin dengan larutan perendam yaitu air, sehingga terjadi perpindahan molekul air dari daging ikan kelarutan perendam. Melalui proses perpindahan 
molekul ini maka formalin yang ada pada daging ikan asin akan larut dalam larutan perendaman yaitu air, formalin mempunyai sifat larut dalam air karena formalin bersifat polar dan air juga bersifat polar (Berhimpon, 2006).

Kelarutan formalin dalam air tergantung pada tingginya temperatur yang digunakan, kelarutan suatu zat cair dalam pelarut air akan semakin tinggi apabila suhunya dinaikkan. Adanya panas (kalor) mengakibatkan semakin renggang dan menjauh posisi jarak antar molekul zat cair dari pelarutnya, merenggangnya jarak antar molekul zat cair dengan pelarut menjadikan kekuatan gaya antar molekul tersebut menjadi lemah sehingga mudah terlepas oleh gaya tarik pada molekul-molekul air. Hal ini disebabkan karena gas yang terlarut di dalam air akan terlepas meninggalkan air seiring dengan bertambahnya suhu yang meningkat sehingga terjadi perubahan fase, fase adalah keadaan materi yang seragam di seluruh bagiannya, bukan hanya dalam komposisi kimianya (Atkins, 1996).

\subsection{Perendaman dalam Air dengan Variasi Waktu}

Proses pengurangan kadar formalin dilakukan dengan perendaman menggunakan suhu terbaik yaitu $70{ }^{\circ} \mathrm{C}$ dengan variasi waktu yang berbeda, 10, 15, 20, dan 25 menit. Perlakuan yang digunakan adalah sama dengan perlakuan sebelumnya, ikan asin direndam dalam air pada suhu $70{ }^{\circ} \mathrm{C}$ pada masing-masing waktu, hasil absorbansi dari masing-masing waktu memperlihatkan bahwa pada waktu 25 menit dengan nilai absorbansi rata-rata dari tiga kali ulangan yaitu 3,5 ppm, hasil ini merupakan hasil absorbansi ikan asin yang terendah dengan asumsi bahwa kadar formalin yang ada pada daging ikan asin larut dalam air dan menguap pada suhu 70 ${ }^{\circ} \mathrm{C}$, nilai absorbansi pada waktu 25 menit lebih rendah dibandingkan dengan nilai absorbansi dengan waktu yang lainnya.

\section{Kesimpulan}

Penurunan kadar formalin terbaik pada ikan asin dilakukan dengan menggunakan suhu $70 \mathrm{C}$ dan lama perendaman 25 menit.

\section{Daftar Pustaka}

Atkins, P.W. 1996. Kimia Fisik Jilid 2, Edisi 4. Jakarta: Erlangga.

Berhimpon, S. 2006. Formalin Pada lkan (Suatu Kasus Pembelajaran). Manado: MD Press.

Hastuti, S. 2010. Analisis Kualitatif Dan Kuantitatif Formaldehid Pada Ikan Asin Di Madura. Jurusan Teknologi Industri Pertanian. Skripsi. Fakultas Pertanian, Universitas Trunojoyo, Madura.

Ketut, S.F., Marhaendrajaya, I. dan Sukarsono, K. 2008. Studi Efek Kerr untuk Pengujian Tingkat Kemurnian Aquades, Air PAM dan Air Sumur. Berkala Fisika, Vol. 11(1): 9-18.

Kompas. 2013. Radar Yogyakarta. Diakses pada tanggal 15 Agustus 2013.

Rinto, E.A. dan Susila, B.U. 2009. Kajian Pangan (Formalin, Garam dan Mikroba) pada Ikan Sepat Asin Produksi Indralaya. Jurnal Pembangunan Manusia, Vol. 8(2).

Salosa, Y.Y. 2013. Uji Kadar Formalin, Kadar Garam dan Total Bakteri Ikan Asin Tengiri Asal Kabupaten Sarmi Provinsi Papua. Depik, Vol. 2(1): 1015.

Suharna, C. 2006. Kajian Sistem Manajemen Mutu Pada Pengolahan Ikan Jambal Roti di Pangandaran Kabupaten Ciamis. Jurnal Penelitian. Universitas Diponegoro, Semarang.

Susianawati, R. 2006. Kajian Penerapan GMP dan SSOP pad Produk Ikan Asin Kering dalam Upaya Peningkatan Keamanan Pangan di 
Kabupaten Kendal. Tesis. Universitas Diponegoro, Semarang.

Ruus, O.V. 2009. Pengaruh Konsentrasi Larutan Garam dan Lama Pengeringan terhadap Mutu Ikan
Layang (Decapterus sp) Asin dengan Kadar Garam Rendah. Skripsi. Fakultas Perikanan dan Ilmu kelautan Universitas Sam Ratulangi, Manado. 